\title{
Use of Landsat 8 OLI Images to Assess Groundwater Potential Areas in the Bamun Plateau: Cameroon Volcanic Line (CVL)
}

\author{
Oumar Farouk Mouncherou ${ }^{1,2^{*}}$, Olivier Njikeu2 ${ }^{2}$ Brice Tchakam Kamtchueng1,2, \\ Amidou Kpoumié1,2,3,4, Zakari Mfonka², Oumarou Farikou Mfochive², Yvette Frida Danwe1, \\ Mohammad Bello', Amidou Moundi ${ }^{2}$, Jules Remy Ndam Ngoupayou ${ }^{2}$, Jean Claude Tonga ${ }^{1}$
}

${ }^{1}$ Institute of Mining and Geological Research (IRGM), Yaounde, Cameroon

${ }^{2}$ Department of Earth Sciences, University of Yaounde I, Yaounde, Cameroon

${ }^{3}$ Department of Earth Sciences, University of Maroua, Maroua, Cameroon

${ }^{4}$ Spatiale Studies Center of the Biospher, UMR 5126, CNRS-CNES-IRD-UPS, IUT Paul Sabatier, Toulouse, France

Email: *omouncherou@yahoo.fr

How to cite this paper: Mouncherou, O.F., Njikeu, O., Kamtchueng, B.T., Kpoumié, A., Mfonka, Z., Mfochive, O.F., Danwe, Y.F., Bello, M., Moundi, A., Ngoupayou, J.R.N. and Tonga, J.C. (2020) Use of Landsat 8 OLI Images to Assess Groundwater Potential Areas in the Bamun Plateau: Cameroon Volcanic Line (CVL). Journal of Water Resource and Protection, 12, 558-576. https://doi.org/10.4236/jwarp.2020.127034

Received: April 27, 2020

Accepted: July 7, 2020

Published: July 10, 2020

Copyright $\odot 2020$ by author(s) and Scientific Research Publishing Inc. This work is licensed under the Creative Commons Attribution International License (CC BY 4.0).

http://creativecommons.org/licenses/by/4.0/

c) (i) Open Access

\begin{abstract}
The problem of groundwater supply in the Bamun plateau situated in the Cameroon Volcanic Line exists and no proper solution has been found so far. This investigation intends to find the suitable groundwater potential zones by overlaying the geomorphologic map, lineament map, lineament density map and lithological map, using visual interpretation of Landsat imagery. The results reveal that about 1921 structural elements, ranging in size, from $30 \mathrm{~m}$ to $5.845 \mathrm{~km}$ with an average length of $671 \mathrm{~m}$ in the field. The total length of the mapped lineaments is approximately $1289 \mathrm{~km}$. The most important lineament (5.845 km length) diagonally crosses the study area in the direction NNE-SSW. In addition to this trend, all others are smaller than $14 \mathrm{~km}$. More than $92 \%$ of lineaments are less than $5 \mathrm{~km}$ in size and only $1.3 \%$ of them are larger than $10 \mathrm{~km}$. Small lineaments are thus the most numerous. According to their directions, the lineaments listed are grouped into 18 directional classes of 10-degree intervals. The rosette of their directions highlights the preferred directions NE-SW, N-S, E-W, NNE-SSW and ENE-WSW. Most of the lineaments clusters in the central part of the area are $\mathrm{N} 20^{\circ}-30^{\circ} \mathrm{E}$ and $\mathrm{N} 60^{\circ}-70^{\circ} \mathrm{E}$ trending lineaments. In this study, the NE-SW trend dominates the structural trend followed by NW-SE and N-S. This can be an indication of the directions of groundwater movement in the area. Alluvial plain and valley have moderate to very good groundwater potential that occurs all over the study area. Porosity of the volcanic rocks varies greatly, but it is everywhere more porous than the underlying, unweathered bedrock. There are essentially three classes (low, average and high) of groundwater potential zones. Hight potential zones are observed
\end{abstract}


around the localities of the Khogham, Mbatpit and Mbam massifs on the one hand and Manswen, Njikwop, Mfelap, Foumban, Njindaré, Nkoundem and Ngwen jigoumbé localities on the other hand. About 13\% of the area has good groundwater potential around the mountains while $58 \%$ is moderately good which corresponds to high to moderate lineament densities situated at average altitude $1200 \mathrm{~m}$ and about $31 \%$ of the area has poor groundwater potential corresponding to low lineament density areas. Moreover, this work has helped develop a detailed lineament map that can be used for mining and hydrological prospecting campaigns.

\section{Keywords}

Bamun Plateau, Aquifer, Lineaments, Landsat Imageries, Groundwater

\section{Introduction}

The tectonic behaviour and the potential to develop groundwater and flow in fractured rocks require effective approaches to characterise fracture. The term fracture refers to joints and faults, as well as varied discontinuities or lineaments over different scales and lithologies due to crustal tectonic driving forces [1]. These discontinuities or lineaments may act as a drain for groundwater movement which results in increased secondary porosity and therefore, can serve as groundwater potential zone. Lineament analysis has been used extensively for geologic interpretation, particularly with the advent of photogeology. In addition, satellite data such as Landsat 8 images provide quick and useful baseline information on the parameters like geology, lithology/structural, geomorphology, soils, land use/cover and lineaments that control the occurrence and movement of groundwater. Landsat 8/LDCM (Landsat Data Continuity Mission) satellite was launched since February 11, 2013 after the disfunctioning of the Landsat 7 sensor. This satellite acquired images in 9 bands from the visible to infrared with the OLI (Operational Land Imager) radiometer and 2 bands in thermal infrared with the TIRS (Thermal Infrared Sensor) radiometer. These Landsat 8 OLI_TIRS images have a radiometric resolution of 16 bits, a swath or scene size of $185 \mathrm{~km} \times 185 \mathrm{~km}$, obtained at an altitude of $705 \mathrm{~km}$, constituted of 11 bands. Free of cloud, there are downloaded from the USGS Earth Explorer website. There are geometrically corrected in advance by the United States Geological Survey (USGS) using the UTM_Zone $32 \mathrm{~N}$ projection with the WGS84 map datum. With the advent of remote sensing techniques, identification of the occurrence of groundwater has become easy and cost-effective procedure. Lineaments that may act as conduits for fluid flow are of particular importance in this investigation.

The problem of groundwater supply in the Bamun Plateau underlain by crystalline rocks still exists and no proper solution has been found so far. Therefore, sustainable groundwater supply in this area requires lineament analysis for the proper sitting of boreholes. Generally, producing wells are located in areas of 
greater lineament density, lineament intersection, and high degree of lineament connectivity.

The main objective of this work is to find the suitable groundwater potential zones by overlaying the geomorphologic map, lineament map, lineament density map, lithological map of the study area and by using visual interpretation of Landsat 8 images.

\section{Material and Methods}

\subsection{Presentation of the Study Area}

The Bamun plateau, located at an average elevation of $1200 \mathrm{~m}$, is one of the main units of the western Cameroon highlands. It is an important unit of the Cameroon Volcanic Line (CVL). Within this mega structure, the Bamun plateau lies between longitudes $10^{\circ} 40^{\prime}-10^{\circ} 56^{\prime} \mathrm{E}$ and latitudes $5^{\circ} 36^{\prime}$ and $6^{\circ} \mathrm{N}$ and covers an average surface area of $900 \mathrm{~km}^{2}$ (Figure 1). The CVL has been described as a succession of horst and grabens that stretches from the Pagalu Island in the Gulf of Guinea to the Lake Chad. Most of the horsts are represented by plateaux, among which the most prominent are the Adamawa plateau and the West $\mathrm{Ca}$ meroonian plateau where the study area is located. Flood basalts outcrop for more than half of each plateau and their emplacement was favoured by reactivations of the Pan African structures marked by $\mathrm{N} 30^{\circ} \mathrm{E}$ deformation that is the major evolutionary character of the CVL [2]. Basaltic lavas of the plateaux (51 to $11 \mathrm{Ma}$ ) bear the signatures of an old volcanic activity as shown by their significant weathering to form deep ferrallitic soils [3] [4] [5] [6] [7].

The geomorphology of the Bamun plateau (Figure 2) is dotted with clumps of all kinds of scope and size variables such as the Mbam Mountain (1921 m), Nkogham $(1724 \mathrm{~m})$, the Batpit Mountain $(2097 \mathrm{~m})$ and about fourthing hills in the southern area. Thus, the eastern and northern borders are raised and overlooking the region by an escarpment of aboout $700 \mathrm{~m}$ to $1000 \mathrm{~m}$. In the western part, the bamun plateau end with the Noun plain by an escarpment of $200 \mathrm{~m}$ to $300 \mathrm{~m}$ in altitude. In the north, it extends to the high grass fields at the foot of the Bamenda area that overlooks the ndop pool creating a steep slope of about $500 \mathrm{~m}$. The remaining $20 \%$ is covered by rhyolites and slag from central volcanism. Volcanic ash from explosive and phreatomagmatic strombolian dynamics have developed some 40 cones that are often breached and about 12 explosion craters and maars, which lie on an orthogneissic basement.

On the geological point of view, the Bamun Plateau belongs to the western basement complex of the Cameroon Volcanic Line, which forms part of the Pan-African mobile belt situated between the West African Craton and the north of the Congo craton. The basement rocks comprise of Precambrian granito-gneissic bedrock outcrops mainly in the North of the study area. The substratum is made up of gneiss with alternating dark and light bands [8] [9]. Another variety of rocks mapped in the area is mylonite made of granite with biotite as the dominant mafic minerals, consisting of fine-grained leucocratic gneiss consisting of $70 \%$ of quartz, 
$25 \%$ of microcline and $5 \%$ of biotite. This forms a major topographic feature and structural unit marker in the area.

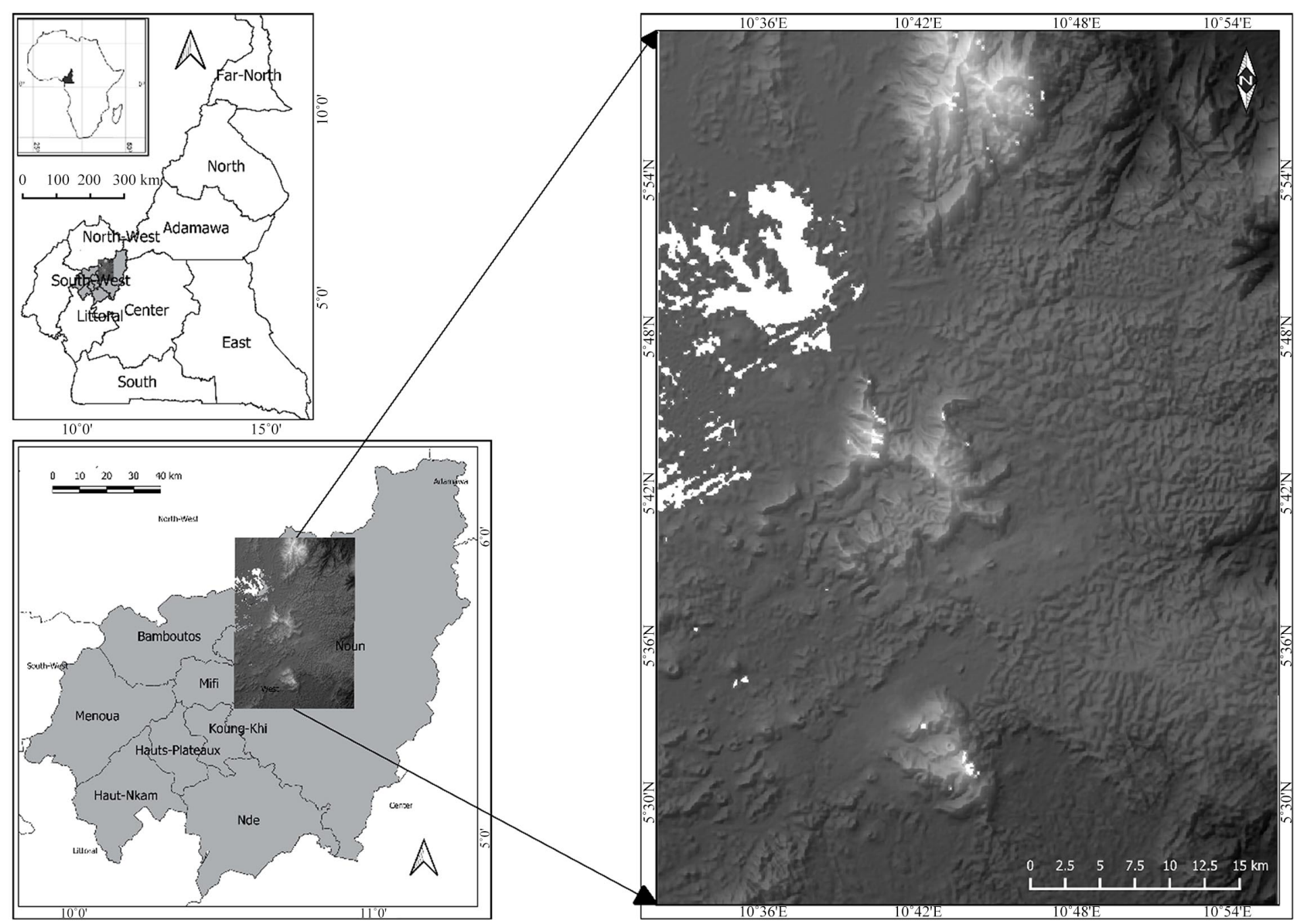

Figure 1. Location map of the study area showing the raw SRTM image used.
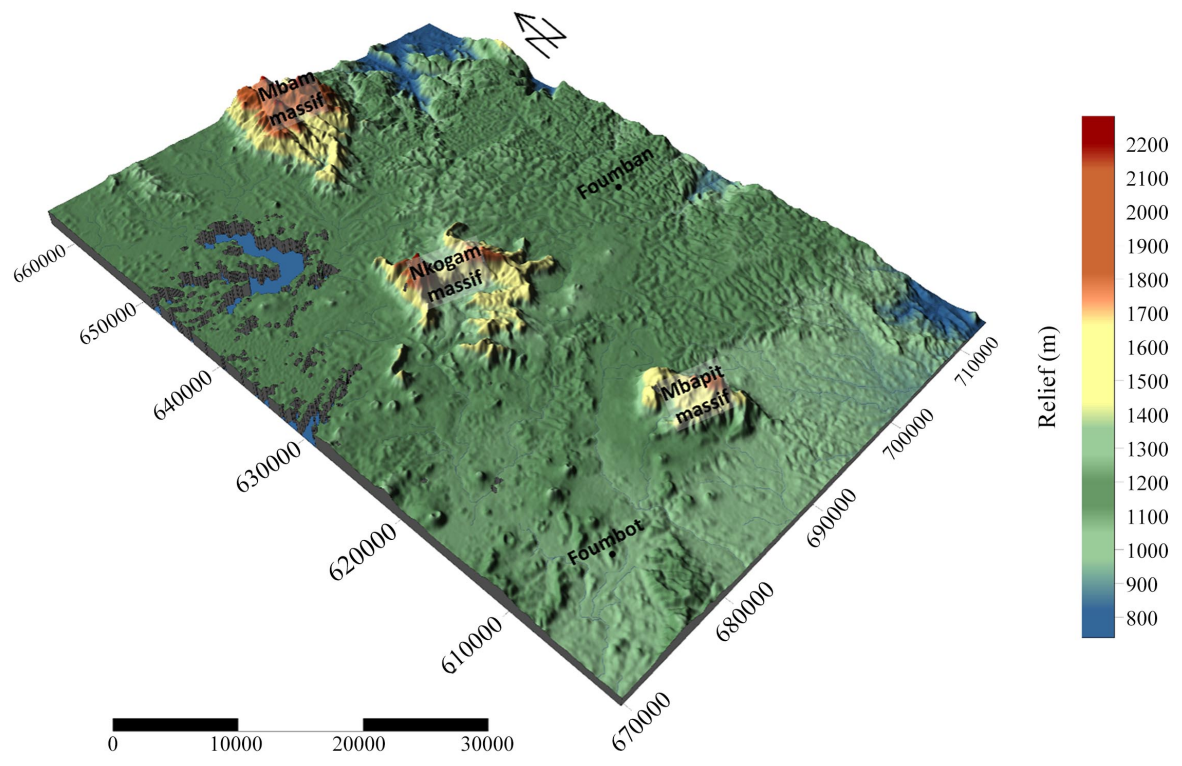

Figure 2. 3D view of the study area. 
The fissural basalts or plateaus basalts cover more than half of the surface area of the plateau. There are in fact transitional basalts that outcrop in the western part (Bangouren) while alkaline basalts outcrop in the East around Foumban and Koutaba [7]. The flood basalts of the Bamun plateau with ${ }^{40} \mathrm{~K} /{ }^{40} \mathrm{Ar}$ ages of 51 and $46 \mathrm{Ma}$ respectively would represent the oldest dated lavas from the CVL. Ten geological features were identified in the area (Figure 3).

\subsection{Materials and Types of Data Employed}

The data used in this study included: 1) Landsat 8 OLI_TIRS images (Path 186 and Row 056) acquired on December 15, 2013, free of cloud and downloaded from the USGS Earth Explorer website. Map projection: UTM_Zone 32; Datum: WGS84;

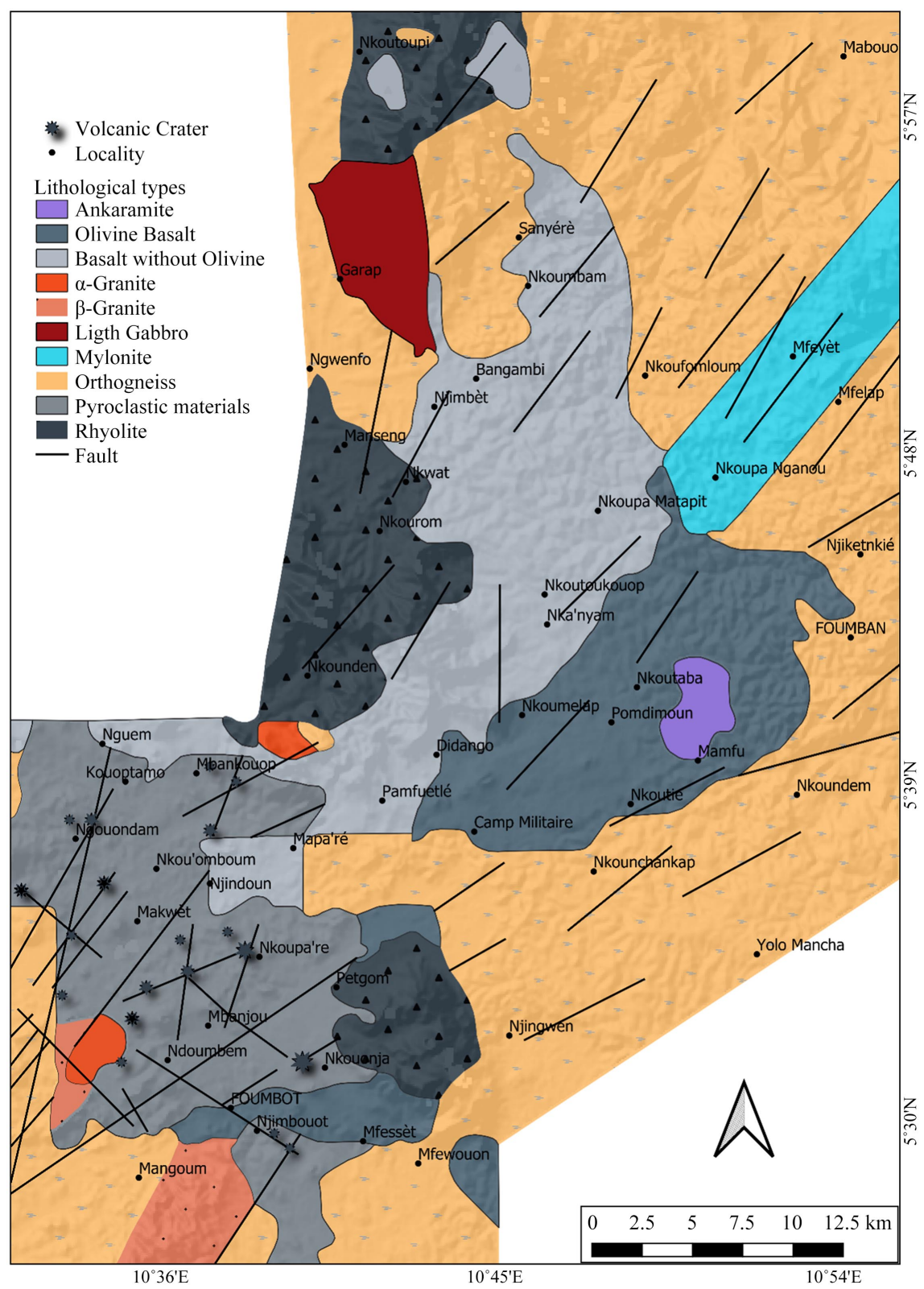

Figure 3. Geological map of the study area. 
2) SRTM satellite image of 2014 covering the explored area; 3) the geological informations was gotting from Dumort [10], the geological map of Wum-Banyo [11] and the geological map of the area at the scale of $1 / 500,000$ [12]; and 4) topographic map of 1/200,000 scale covering the study area. The main characteristics of the Landsat satellite images used in this study are presented in Table 1. The softwares used for processing and analysis of the different maps and images are: ArcGIS 10.2, Qgis 3.4, ENVI 5.3; PC geomatica 2016 and Rockworks.

\subsection{Methods}

\subsubsection{Pre-Processing of the Satellite Images}

There is a wide variety of techniques for the improvement of the satellite images quality. The choice of a method depends on its application, the type of data used, the experience and preferences of the image analysed. Different types of treatments were carried out in this work. These treatements aim at obtaining an enhanced spectral signature for the lithology and to make the lineament easily detectable. Measurement requires a pre-processing which assumes a good sensor and conditions of data acquisition. Thus, some authors compare the quality and the quantity of lineaments extracted from satellite images (Landsat ETM+ and ASTER, Landsat 8, Sentinel-2 and Radar Sentinel-1), and concluded that the higher the spatial resolution, the higher the quality and quantity of the lineament [13] [14].

In this work, the pre-processing operations consisted of atmospheric and radiometric corrections without the geometric correction because the Lansat 8 OLI images are geometrically corrected in advance by the United States Geological Survey (USGS) using the UTM_Zone 32N projection with the WGS84 map datum. Then followed the PanSharpening. The atmospheric correction permitted us to obtain the Top Of Atmosphere (TOA) reflectance, which was converted into surface reflectance using the Dark Object Subtraction (DOS) method as well as [15] [16].

\section{1) Images contrast enhancement}

After the correction of the images, they were improved in order to increase their visual perception and to better visualize discontinuities. Thus, we first of all created a virtual band set, then we made: the transformation in Principal Component Analysis (PCA), the exportation in 8-bit (gray scale), Pan Sharpening and the spatial filtering. The raw Landsat 8 OLI (Operational Land Imager) bands were correlated. The good correlation between bands shown in Table 2 reveal the significant redundancy of the information contained in the Landsat 8 OLI images.

\section{Pan Sharpening}

According to [17] "Pan Sharpening" is shorthand for "Panchromatic sharpening". It means using a panchromatic (single band) image to "sharpen" a multispectral image. In this sense, to "sharpen" means to increase the spatial resolution of a multispectral image. 
Table 1. Spectral bands of the Landsat 8 image used in this study and their characteristics.

\begin{tabular}{lccc}
\hline Bands & Spectral bands & Wavelength & Spatial resolution \\
\hline & \multicolumn{2}{c}{ Spectral bands of the OLI sensor } \\
Band 1 & Aerosols & $0.433-0.453 \mu \mathrm{m}$ & $30 \mathrm{~m}$ \\
Band 2 & Blue & $0.450-0.515 \mu \mathrm{m}$ & $30 \mathrm{~m}$ \\
Band 3 & Green & $0.525-0.600 \mu \mathrm{m}$ & $30 \mathrm{~m}$ \\
Band 4 & Red & $0.630-0.680 \mu \mathrm{m}$ & $30 \mathrm{~m}$ \\
Band 5 & Near IR & $0.845-0.885 \mu \mathrm{m}$ & $30 \mathrm{~m}$ \\
Band 6 & Medium IR & $1.560-1.660 \mu \mathrm{m}$ & $30 \mathrm{~m}$ \\
Band 7 & Medium IR & $2.100-2.300 \mu \mathrm{m}$ & $30 \mathrm{~m}$ \\
Band 8 & Panchromatic & $0.500-0.680 \mu \mathrm{m}$ & $15 \mathrm{~m}$ \\
Band 9 & Cirrus & $1.360-1.390 \mu \mathrm{m}$ & $30 \mathrm{~m}$ \\
& Spectral bands of the TIRS sensor & $100 \mathrm{~m}$ \\
Band 10 & Medium IR & $10.30-11.30 \mu \mathrm{m}$ & $100 \mathrm{~m}$ \\
Band 11 & Medium IR & $11.50-12.50 \mu \mathrm{m}$ & \\
\hline
\end{tabular}

Table 2. Correlation matrix of the raw Landsat 8 OLI bands used (2, 3, 4, 5, 6 and 7).

\begin{tabular}{ccccccc}
\hline Correlation & Band 2 & Band 3 & Band 4 & Band 5 & Band 6 & Band 7 \\
\hline Band 2 & 1.000000 & 0.950064 & 0.810511 & 0.285629 & 0.433752 & 0.510453 \\
Band 3 & 0.950064 & 1.000000 & 0.897692 & 0.454827 & 0.636801 & 0.682597 \\
Band 4 & 0.810511 & 0.897692 & 1.000000 & 0.265552 & 0.742035 & 0.848404 \\
Band 5 & 0.285629 & 0.454827 & 0.265552 & 1.000000 & 0.623156 & 0.411483 \\
Band 6 & 0.433752 & 0.636801 & 0.742035 & 0.623156 & 1.000000 & 0.941078 \\
Band 7 & 0.510453 & 0.682597 & 0.848404 & 0.411483 & 0.941078 & 1.000000 \\
\hline
\end{tabular}

A multispectral image contains a higher degree of spectral resolution than a panchromatic image, while often a panchromatic image will have a higher spatial resolution than a multispectral image. A pansharpened image is an image obtained from a pixel level fusion technique between the multispectral and panchromatic images which gives the best of both image types, high spectral resolution and high spatial resolution. To this end, the band 8 (panchromatic band) was merge with the other bands $(2,3,4,5,6$ and 7$)$ in other to enhance their quality (Figure 4). The task was done using the Semi-Automatic Classification plugin of Qgis 3.10.

Note that for a successful pansharpening, the image must be registered closely enough. But in the case of multispectral data alone, the individual bands of the image must be co-registered. 


\section{The principal component analysis}

The principal component analysis (PCA) is known as the Karhunen-Loeve transform or the Hotelling transform, which is widely used in signal processing, statistics, and many other applications [18]. It involves a mathematical procedure that transforms a number of correlated variables into a set of uncorrelated variables called principal components [19].

In this work, the PCA was carried out in order to overcome the redundancy and to improve the contrast of the image. For this, the closeness between two images can be quantified in terms of the correlation function [20]. The correlation matrix (Table 2) of the Landsat 8 OLI bands (2, 3, 4, 5, 6 and 7) used testify the closeness of these images. Meaning that they are suitable for PCA. The correlation (Corr) coefficient is computed from:

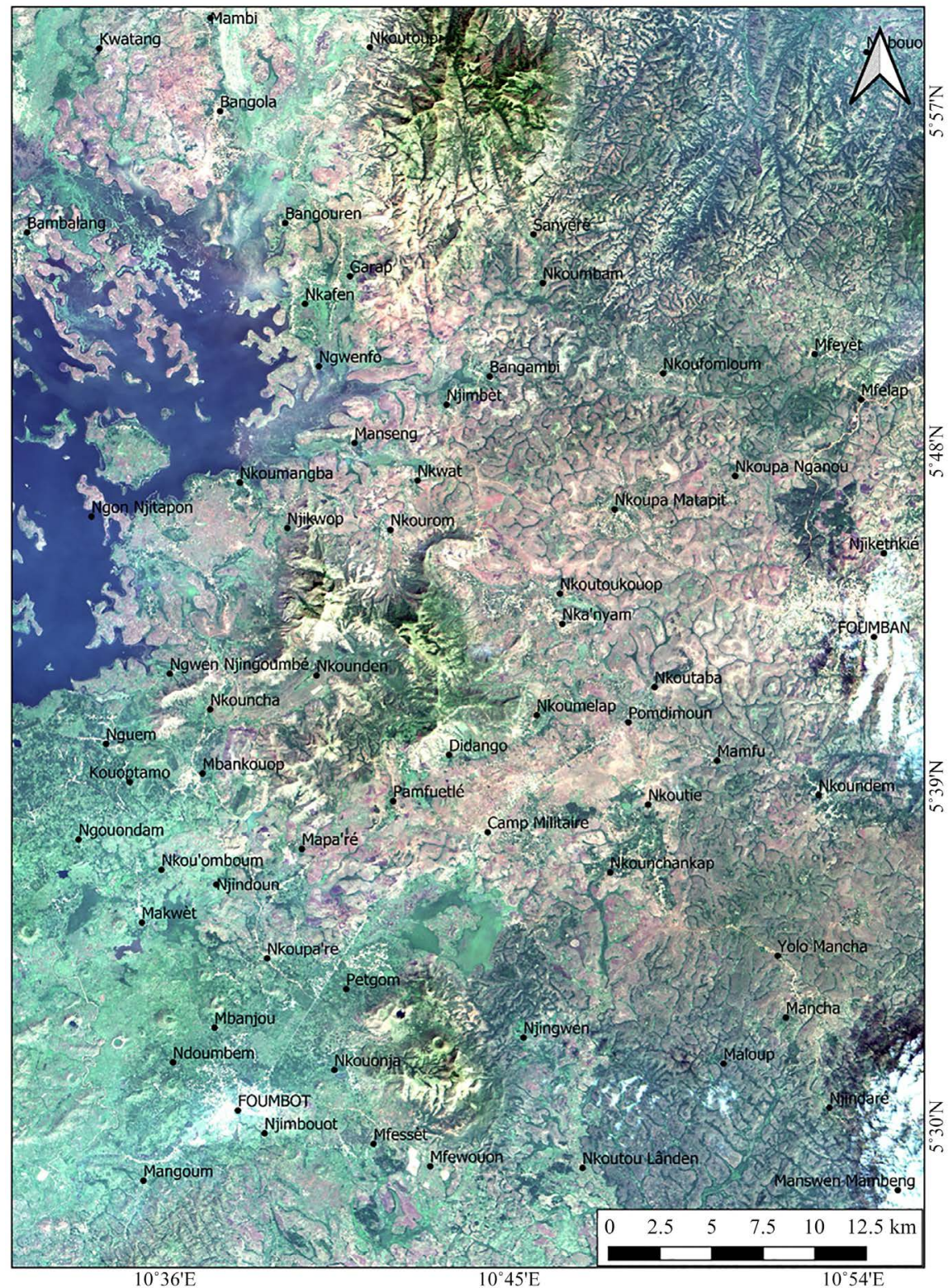

Figure 4. RGB 432 coloured composite image of the study area. 


$$
\operatorname{Corr}(A / B)=\frac{\sum_{i=1}^{M} \sum_{j=1}^{N}\left(A_{i, j}-\bar{A}\right)\left(B_{i, j}-\bar{B}\right)}{\sqrt{\sum_{i=1}^{M} \sum_{j=1}^{N}\left(A_{i, j}-\bar{A}\right)^{2} \sum_{i=1}^{M} \sum_{j=1}^{N}\left(B_{i, j}-\bar{B}\right)^{2}}}
$$

(A and $\mathrm{B}$ are two set of images between which the correlation is computed and $\bar{A}$ and $\bar{B}$ are panchromatic oposite images; $i, j, M$ and $N$ are other coefficients; this $\sum$ is sum; Corr means correlation).

\section{2) Spatial filtering and shaded relief images}

After the fusion and the enhancement of the images, the directional convolution filtering was performed for visual interpretation and manual lineament extraction. This technique of spatial filtering of the image consists of the recalculation of the value of each pixel by analyzing the surrounding radiometry. In our case, the images were filtered with a sun incidence angle of $345^{\circ}$, an altitude $45^{\circ}$ and an elevation factor of 3. The raw SRTM image was treated in "Surfing in shaded relief mode", it was first of all projected using the cubic convolution method, afterwhich shaded relief images were created for various sun azimuths with an altitude of $45^{\circ}$. Thus, four different sun orientations were used in this study: $315^{\circ}, 45^{\circ}, 135^{\circ}$ and $225^{\circ}$ (Figure 5).
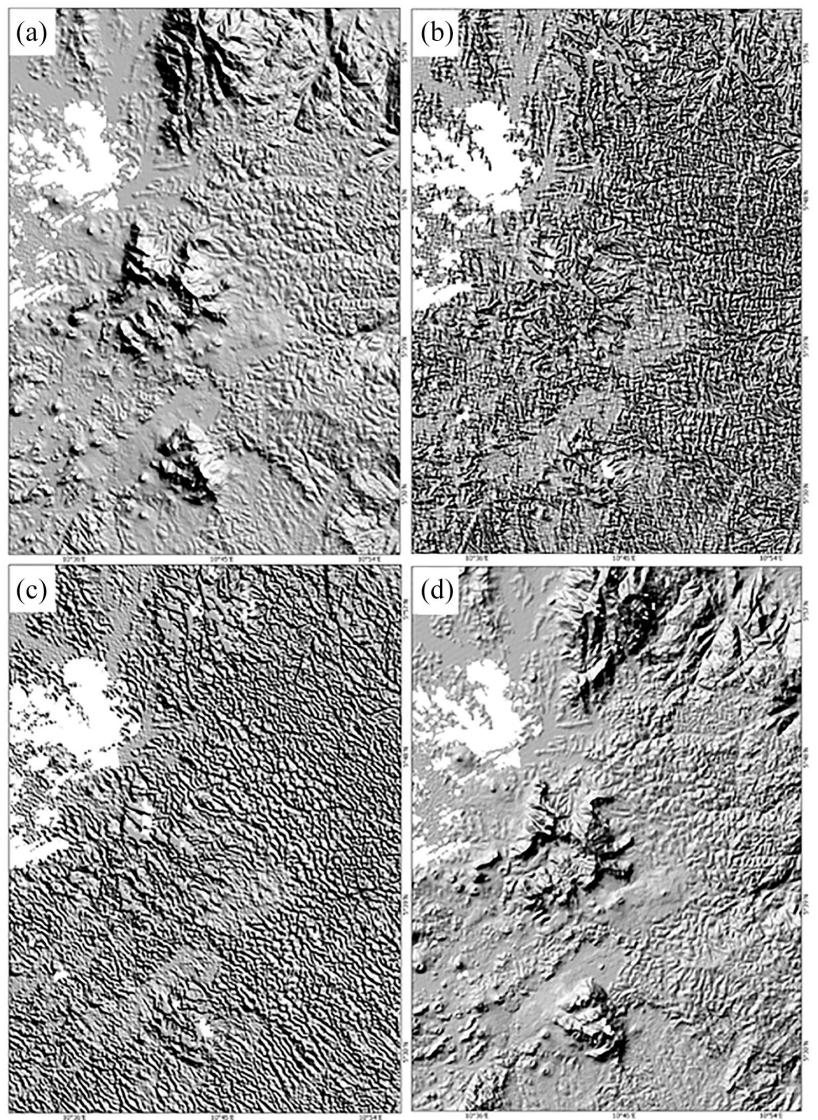

Figure 5. Shaded relief images with varying sun azimuth and angle in the four main directions: 1) NE-SW direction (45), 2) SE-NW direction (135), 3) SW-NE direction (225), and 4) NW-SE direction (315). 


\subsubsection{Lineaments Mapping}

A quantitative analysis was carried out to determine the distribution of lineament orientations and lengths in the Bamun Plateau. In this area, most of the fracture element data can be collected at road trenches, quarries, and outcrops with the exception of fracture length which is sometimes difficult to accurately trace because they are partly buried by soils and vegetation. In this work, two methodological approaches for lineament identification and extraction from remotely sensed data were used according to [21]. To achieve this, by the first approach, all the linear structures observed on the enhanced satellite image were digitalized using manual digitizing techniques. While the second approach implied the automatic extraction of the other lineaments, made using the software PC geomatica 2016.

\subsubsection{Validation of the Lineament Map}

The validation process was performed by integrating the spatial data for a good validation of the lineaments obtained by photo interpretation. The field reality is the most reliable way to validate the linear maps because the extension faults are recognizable on the ground. As part of our study, we used the geological map (Figure 3), the hydrographic network map (Figure 6) and the road network of the studied area and field data to validate the fracture map of the area explored. The process consisted of identifying and listing all the faults parallel to the straight stream segments by taking in consideration the identical lineaments on the different maps, and then combining them with the field data using a software package (GIS) to draw a structural map of the area. A detailed map of the lineaments can thus be used in hydrogeology for the drilling of boreholes, mineral prospecting and for a better interpretation of the geological structures observed on the field.

\section{Results and Discussion}

\subsection{Lineaments Mapping}

The goal was to detect all linear structures that can significantly influence the fracturation of the study area. All applied filters were intended to enhance certain features of the image. The different results presented in Figure 7 raise the distribution of the lineaments in the study area.

Data compiled from field observations were collected and presented in Table 3. In fact, the high relief form a backbone of the highlands from the Gulf of Guinea to the Tibesti through northern Cameroon along an axis called $\mathrm{N} 30^{\circ} \mathrm{E}$ line of Cameroon. However, the highlands of Adamawa have an orientation $\mathrm{N} 73^{\circ} \mathrm{E}$ derived from the Pernambuco fracture in Brazil. According to the data compiled, there are four major structural directions in Cameroon with predominance of directions $\mathrm{N} 20^{\circ} \mathrm{E}$ to $\mathrm{N} 60^{\circ} \mathrm{E}$, which are the main [22] results of plate movement. Although the movement of plates does not seem better followed by lack of measuring instrument. Cameroon recorded frequent seismic movement of scale, size and variable location. Thus, there was an earthquake in 1987 in Magba, site of 
Table 3. Measurement of deformations plans on the bedrock of the Plateau Bamun.

\begin{tabular}{ccccccccc}
\hline PLANS & TRENDS & DIPS & PLANS & TRENDS & DIPS & PLANS & TRENDS & DIPS \\
\hline P1 & N70 & $15^{\circ} \mathrm{SE}$ & P1 & N140 & $20^{\circ} \mathrm{NE}$ & P1 & N18 & $20^{\circ} \mathrm{ESE}$ \\
P2 & N00 & $18^{\circ} \mathrm{E}$ & P2 & N010 & $30^{\circ} \mathrm{ESE}$ & P2 & N28 & $10^{\circ} \mathrm{ESE}$ \\
P3 & N110 & $08 \mathrm{SSW}$ & P3 & N050 & $10^{\circ} \mathrm{SE}$ & P3 & N65 & $15^{\circ} \mathrm{SSE}$ \\
P4 & N85 & $25^{\circ} \mathrm{SSE}$ & P4 & N040 & $70^{\circ} \mathrm{SE}$ & P4 & N60 & $25^{\circ} \mathrm{SE}$ \\
P5 & N70 & $40^{\circ} \mathrm{SE}$ & P5 & N080 & $45^{\circ} \mathrm{SSE}$ & P5 & N150 & $20^{\circ} \mathrm{SW}$ \\
P6 & N65 & $25^{\circ} \mathrm{SE}$ & P6 & N042 & $63^{\circ} \mathrm{SE}$ & P6 & N75 & $25^{\circ} \mathrm{SSE}$ \\
P7 & N50 & $30^{\circ} \mathrm{SE}$ & P7 & N030 & $70^{\circ} \mathrm{ESE}$ & P7 & N170 & $20^{\circ} \mathrm{ENE}$ \\
P8 & N110 & $25^{\circ} \mathrm{SSW}$ & P8 & N010 & $80^{\circ} \mathrm{ESE}$ & P8 & N45 & 00 \\
P9 & N130 & $30^{\circ} \mathrm{NE}$ & P9 & N085 & $20^{\circ} \mathrm{SSW}$ & P9 & N100 & $15^{\circ} \mathrm{NNE}$ \\
P10 & $\mathrm{N} 135$ & $15^{\circ} \mathrm{SW}$ & P10 & N135 & $15^{\circ} \mathrm{SW}$ & P10 & N160 & $10^{\circ} \mathrm{ENE}$ \\
\hline
\end{tabular}

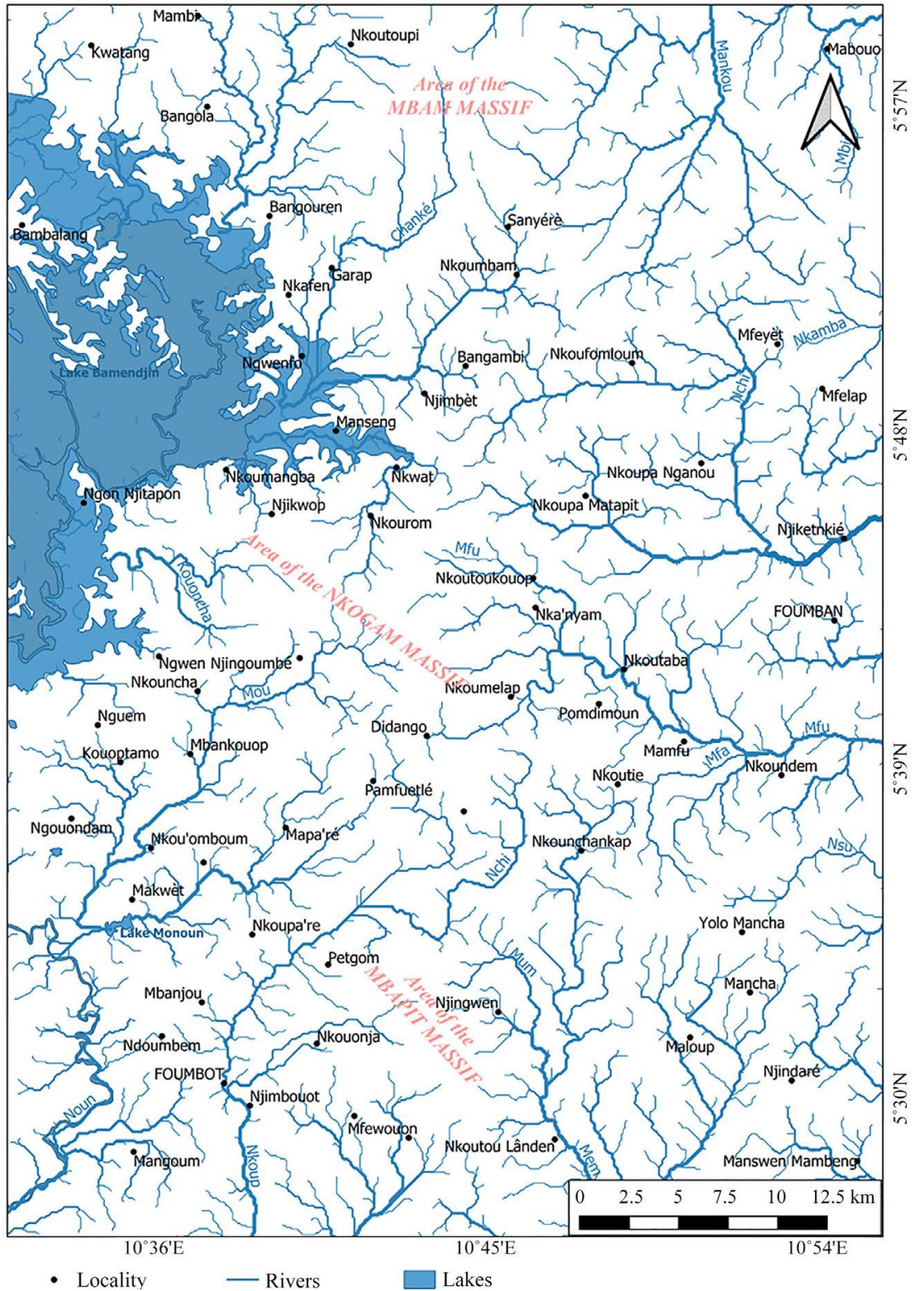

Figure 6. Hydrographic network of the Bamun Plateau. 


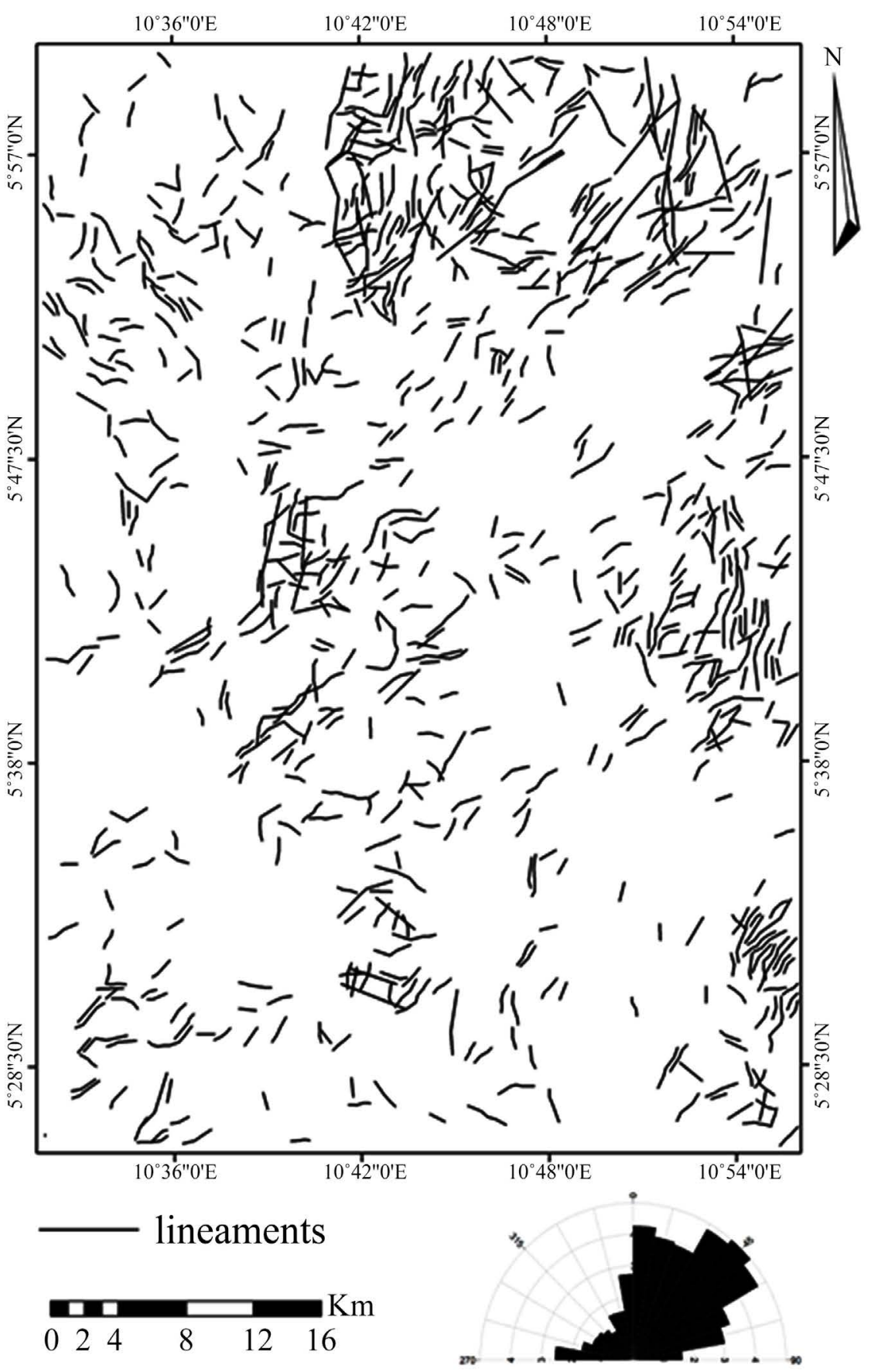

Figure 7. Lineaments map of the study area.

the Mape dam, located on the Foumban Pan-African fault (N58 ${ }^{\circ}$ E). In 1990, another earthquake was recorded at Ndu in the North West another locality of the high western lands.

Physically, Bamun centre consists of a set of granite plateaux, tectonized and deeply dissected. There are the most brittled structures shown in mylonite and orthogneiss outcrops in Foumban, Foumbot, Koutaba and Bagourain. They are generally in a plane $\mathrm{E}-\mathrm{W}$ in the sub vertical direction. The $\mathrm{N} 30^{\circ} \mathrm{E}$ and $\mathrm{N} 120^{\circ} \mathrm{E}$ man- 
agement is predominant. Like all other structural elements faults are common in mylonite. They are macroscopically expressed in the mylonite of Foumban in vertical form. These are rich in mylonite parallel cracks, more or less parallel to the layering. Two main fracture directions $\left(\mathrm{N} 140^{\circ} \mathrm{E}\right.$ and $\left.\mathrm{N} 55^{\circ} \mathrm{E}\right)$ are identified. We can also distinguish in this series: fractures diaclases and the vein injections joints. They are subvertical with a major direction in the range of $\mathrm{N} 30^{\circ} \mathrm{E}$ and $\mathrm{N} 120^{\circ} \mathrm{E}$. The vein injections are granitic fillings visible on the mylonite Foumban. These subvertical orientation veins E-W, NNE-SSW intersect them (Figure 8).

\subsection{Frequency and Spatial Location of Fractures}

The lineament and frequency map (Figure $4 \&$ Figure 5) show that the fractures distribution is homogeneous. The lineament number is in the range of 0 and 7. The majority of the fractures are located on the hard rocks which refer to igneous and metamorphic rocks. They are mylonite, gneiss and granite.

The number of lineaments on the map is about 1921 structural elements, ranging in size from $30 \mathrm{~m}$ to $5845 \mathrm{~m}$, with an average length of $671 \mathrm{~m}$ in the field. The total length of the mapped lineaments is approximately $1289 \mathrm{~km}$. The most important lineament (5845 m length) diagonally is oriented NNE-SSW. In addition to this trend, all others are smaller than $14 \mathrm{~km}$, more than $92 \%$ of lineaments are less than $5 \mathrm{~km}$ in size, only $1.3 \%$ of them are larger than $5 \mathrm{~km}$; small lineaments are thus the most numerous. According to their directions, the lineaments listed are grouped into 18 directional classes of 10 degrees interval. The rosette of their directions (Figure 8) highlights the preferred directions NE-SW, N-S, E-O, NNE-SSW and ENE-WSW.

\subsection{Orientation of the Lineaments}

The orientation of the lineaments is analysed by drawing rose diagrams (Figure 8). Even though these diagrams are not length-weigthted, they can indicate on each occasion what are the most dominant directions of fractures. This analysis is very important for the study of groundwater flow, as in most cases the orientation of the fractures is identical to the orientation of the preferential flow path.

Here the fault rose plot indicates two sets of orientation classes. The main two classes are NE and SW strike, while others have NW and SE strike. The uniformity of fracture orientation becomes an additionnal indication for the hydrogeological regime.

\subsection{Size of the Lineaments}

The length of 1921 interpreted lineaments range from $30 \mathrm{~m}$ to $5845 \mathrm{~m}$ (Figure 9). Fracture dimensions (aperture and apparent aperture) are very difficult to define and the depth of the apertures makes the measurement even more complicated. Nevertheless, length measurements can be taken relatively easily and they are also significant, since a fracture with a greater length affects the groundwater flow in a more dominant way than those of smaller length. 


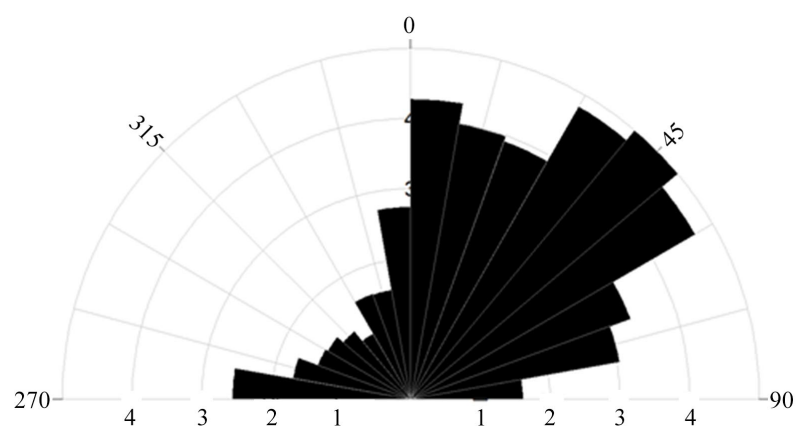

Figure 8. Lineaments orientations.

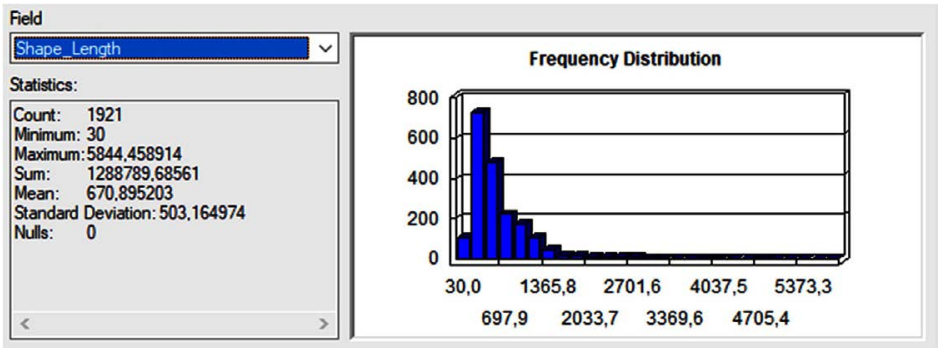

Figure 9. Lenght and distribution of the lineaments in the study area.

\subsection{Density of the Lineaments}

The purpose of the fracture density analysis is to calculate frequency of the fractures per unit area. The map shows the concentration of the lineaments of the Bamoun Plateau (Figure 10). There are essentially three classes (low, average and high). The drainage density represents the precipitation amount which could seep into the basement. Therefore, the higher the drainage density is, the higher the recharging probability is [23]. The map in Figure 10 shows that hight density is observed around the localities of the Khogham, Mbatpit and Mbam massifs on the one hand and Manswen, Njikwop, Mfelap, Foumban, Njindaré, Nkoundem and Ngwen jigoumbé localities on the other hand. Mountains areas and hills have high densities of lineaments which justify the preponderance of perched groundwater and the quality of the water resources. The degree of hydraulic interconection between the above lithologic units as surface water circulates through these discontonuities is verified in the next consideration (degree of fractures intersection). On the other hand very low density is observed in the volcanic rocks $\left(1 \mathrm{~km} / \mathrm{Sq} \cdot \mathrm{Km}^{2}\right)$, and in areas where combinations of more lithological features dominate. This verifies that these lithologies are affected by tectonic activity. However, low elevation areas which are generally wetted can have aquifer whose management for quality remains complicated.

\subsection{Degree of Lineaments Intersection}

The density and degree of lineament connection determine the level of anisotropy of groundwater flow in the fractured aquifer, as in an environment with a high degree of interconnection where groundwater flow is steadfast. Fracture intersection density map shows the frequency of intersections per unit area. There- 
fore, the intersection density maps were used to classify the areas of diverse fracture orientations. If the fractures do not intersect in the aforesaid area, the resultant map will be represented by a plain map with almost no density contours and the fractures will almost be parallel or sub-parallel. The groundwater potential zones map of the study area (Figure 10) indicates areas with very high density of lineaments.

The flow of water is generally from east to west and north to south in the plain of Noun, in front of the rest of the Bamun plateau. Which is justified by the hydraulic activity of network faults and tectonic deformation that have severely affected the region.

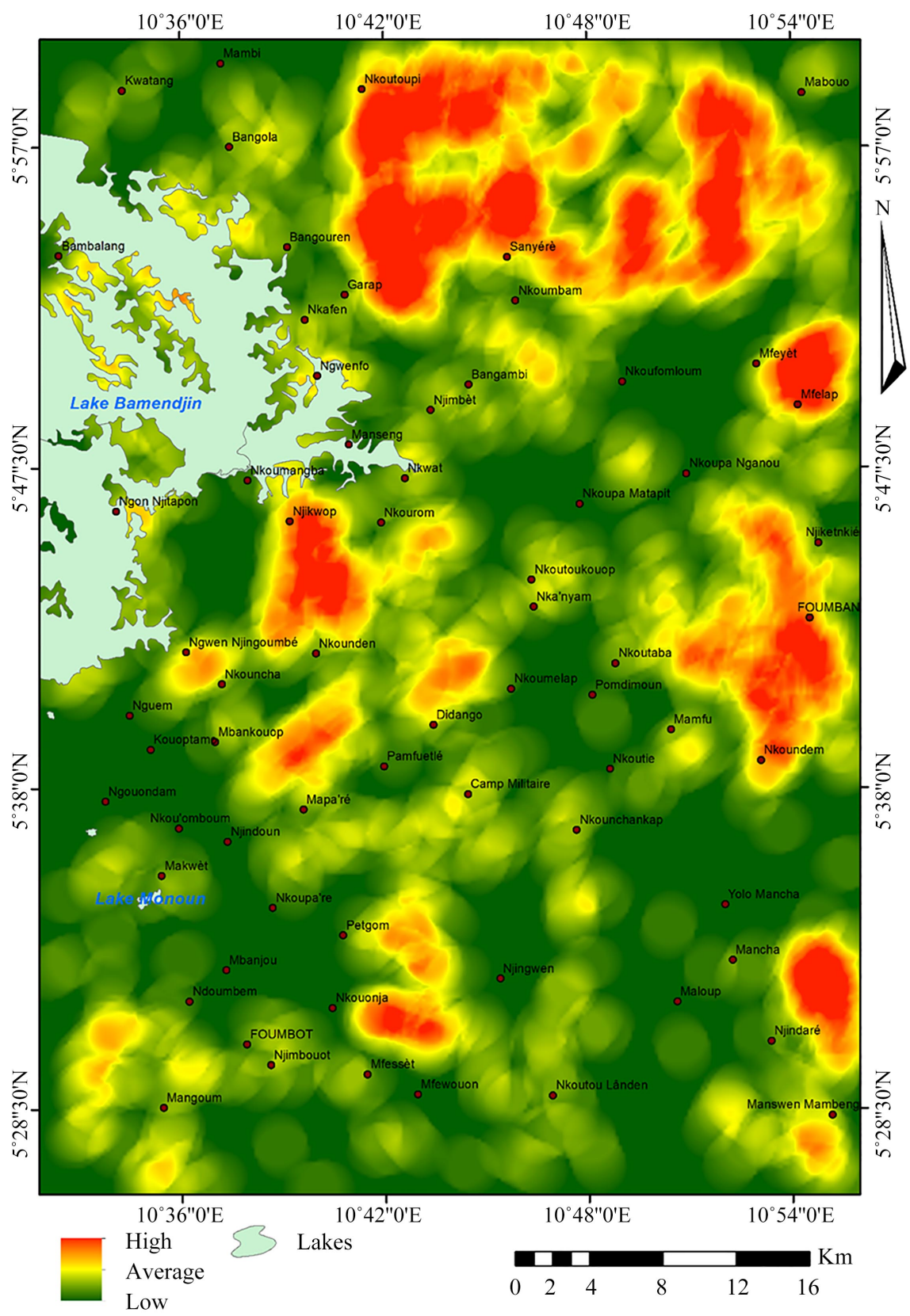

Figure 10. Groundwater potential zones map. 


\subsection{Groundwater Potentiality}

The groundwater yield of these crystalline rocks is directly depending on the degree to which the rock has been fractured. Presence of weak planes in the rocks makes them susceptible to develop secondary porosity. Contact zones between crystalline-rock types are also favorable places for the location of wells yielding large volumes of water. Wells that penetrate no fractures will yield little or no water. Wells that penetrate only a few small shallow fractures initially may have an adequate yield; however, after the fractures are drained, well yield can suddenly decrease and the sustained yield may be small. Wells that penetrate only one large fracture have similar yield characteristics. Wells that penetrate several small fractures as well as one large one probably will have a large sustained yield. Wells that penetrate intensely fractured rock will be the most dependable in terms of sustained yield. Steeply inclined fractures are commonly expressed at the land surface as lineaments; and wells drilled along such lineaments or along known fracture traces consistently yield more water than randomly located wells.

Most of the lineament clusters in the central part of the area and are $\mathrm{N} 20^{\circ}$ $30^{\circ} \mathrm{E}$ and $\mathrm{N} 60^{\circ}-70^{\circ} \mathrm{E}$ trending lineaments. In this study, NE-SW dominates the structural trend followed by NW-SE and N-S. This can be an indication of the directions of groundwater movement in the area. From Table 1 and the geomorphological map (Figure 11) alluvial plain and valley fills have moderate to very good groundwater potential that occur all over the study area. Porosity of the volcanic rocks varies greatly, but it is everywhere more porous than the underlying unweathered bedrock. We can distinguish $13 \%$ of the area has good potential around the mountains; about $58 \%$ is moderately good which corresponds to high to moderate lineament densities situated at average altitude $1000 \mathrm{~m}$; while about $31 \%$ of the area has poor ground water potential corresponding to low lineament density areas. Moreover, this work has helped develop a detailed lineament map that can be used for mining and hydrogical prospecting campaigns.

\section{Conclusions}

The aim of this work was to identify suitable groundwater potential zones in the Bamun Plateau using visual interpretation of Landsat 8 OLI_TIRS images. After processing the landsat image and carrying out a very important fieldwork for the validation of the output of Landsat image processing, these following information could be collected. The number of lineaments on the map is about 1921 structural elements, ranging in size from $30 \mathrm{~m}$ to $5845 \mathrm{~m}$ with an average length of $671 \mathrm{~m}$ in the field. The total length of the mapped lineaments is approximately $1289 \mathrm{~km}$. The most important lineament (5.845 km length) diagonally crosses the study area in the direction NNE-SSW. In addition to this trend, all others are smaller than $14 \mathrm{~km}$, more than $92 \%$ of lineaments are less than $5 \mathrm{~km}$ in size, only $1.3 \%$ of them are larger than $10 \mathrm{~km}$; small lineaments are thus the most numerous. According to their directions, the lineaments listed are grouped into 18 directional classes of 10-degree intervals. The rosette of their directions (Figure 8) highlights the preferred directions NE-SW, N-S, E-W, NNE-SSW and ENE-WSW. 


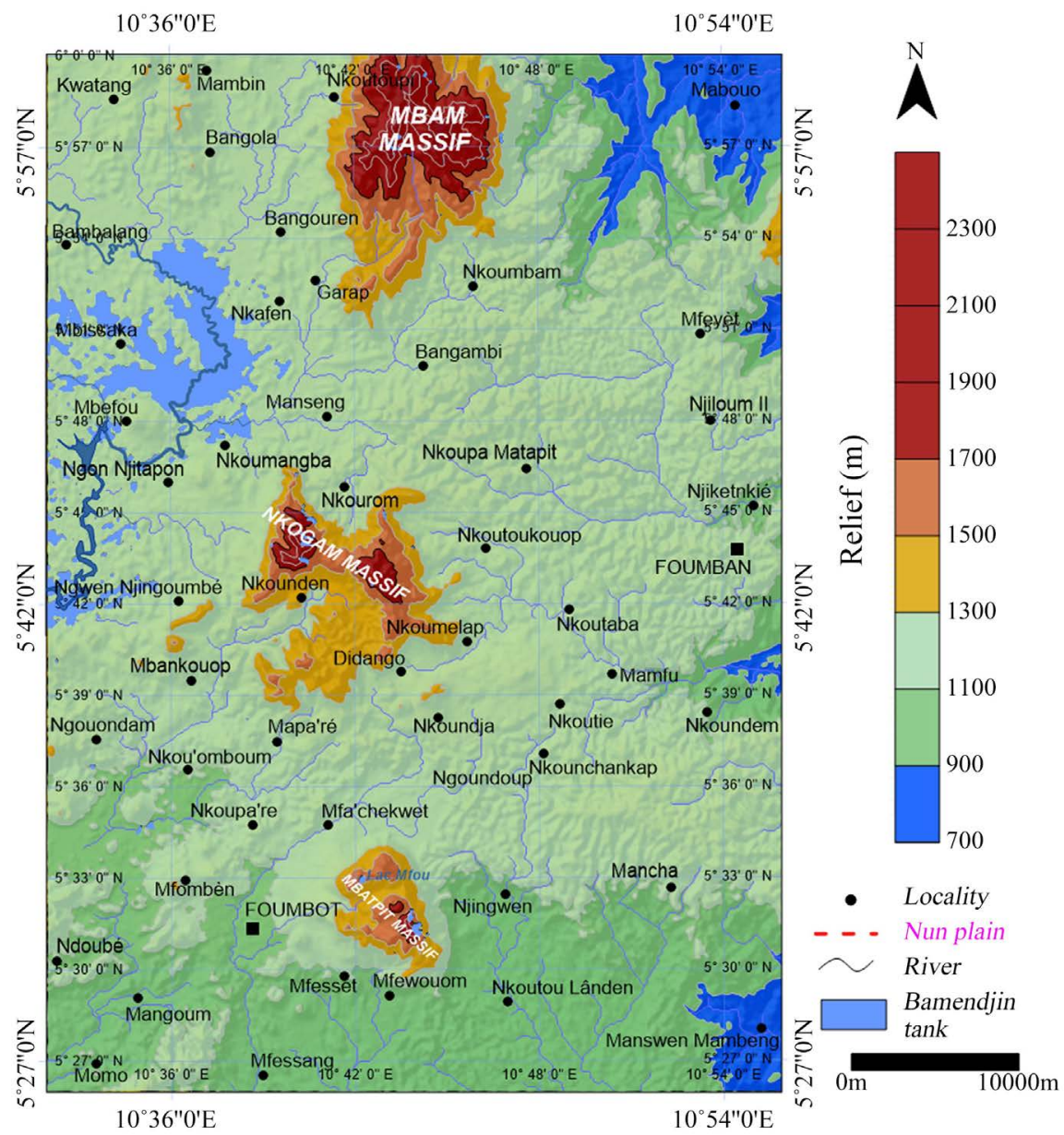

Figure 11. Geomorphology and rivers sources (situated between $1300-1900$ m).

There are essentially three classes (low, average and high) of groundwater potential zones. Hight potential zones are observed around the localities of the Khogham, Mbatpit and Mbam massifs on the one hand and Manswen, Njikwop, Mfelap, Foumban, Njindaré, Nkoundem and Ngwen jigoumbé localities on the other hand.

About $13 \%$ of the area has good groundwater potential; while $58 \%$ is moderately good then and $31 \%$ of the area has poor ground water potential corresponding to low lineament density areas. Moreover, this work has helped develop a detailed lineament map that can be used for mining and hydrological prospecting campaigns.

\section{Conflicts of Interest}

The authors declare no conflicts of interest regarding the publication of this paper.

\section{References}

[1] El Hadani, D. (1997) Télédétection et Systèmes d'Information Géographique pour la gestion et la recherche de l'eau, Géo-Observateur. Les Rapport Thématiques, 1, 28. 
[2] Moreau, C., Regnoult, J.M., Deruelle, B. and Robineau, B. (1987) A New Tectonic Model for the Cameroon Line, Central Africa. Tectonophysics, 139, 317-334. https://doi.org/10.1016/0040-1951(87)90206-X

[3] Fitton, J.G. (1987) The Cameroon Line, West Africa. A Comparison between Oceanic and Continental Alkaline Volcanism in Alkaline Igneous Rocks. Geological Society, London, Special Publications, 30, 223. https://doi.org/10.1144/GSL.SP.1987.030.01.13

[4] Wandji, P. (1995) Le volcanisme récent de la plaine du noun (Ouest Cameroun) Volcanologie, pétrologie géochimie et pouzzolanicité. Thèse Etat Univ. Yaoundé I, Cameroun, 295 p.

[5] Marzoli, A., Piccillo, E.M., Renne, P.R., Bellieni, G., Iacaumin, M., Nyobe, J.B. and Tongwa, A.T. (2000) The Cameroon Volcanic Line Revisited: Petrogenesis of Continental Basaltic Magmas from Lithospheric and Asthenospherc Mantle Sources. Journal of Petrology, 2, 87-109. https://doi.org/10.1093/petrology/41.1.87

[6] Menard, J.-J., Bardintzeff, J.-M., Moundi, A., Wandji, P., Ngounouno, I. and Bellon, H. (2002) Place du magmatisme transitionnel dans le volcanisme de la Ligne du Cameroun. 19è Réunion des Sciences de la Terre, Nantes, 9-12 Avril 2002, 243.

[7] Moundi, A., Wandji, P., Bardintzeff, J.-M., Menard, J.-J., Okomo Atouba, L.-C., Mouncherou, O.-F., Reusser, E., Bellon, H. and Tchoua, F.M. (2007) Les basaltes éocènes à affinité transitionnelle du plateau Bamoun, témoins d'un réservoir mantellique enrichi sous la ligne du Cameroun. Comptes Rendus Geoscience, 339, 396-406. https://doi.org/10.1016/j.crte.2007.04.001

[8] Bessoles, B. (1977) Géologie de l'Afrique: Le craton Ouest-africain. Mém. BRGM, $403 \mathrm{p}$.

[9] Bessoles, B. and Trompettes, R. (1976) Géologie de l'Afrique centrale partie sud et zone mobile soudanaise. Mémoire BRGM N 92 Paris 402 p.

[10] Dumort, J.C. (1968) Carte géologique de reconnaissance et note explicative sur la feuille Douala-Ouest (1500000) République Fédérale du Cameroun. Direction des Mineset de la Géologie du Cameroun. 69 p.

[11] Peronne, Y. (1969) Carte géologique de reconnaissance de Wum-Banyo à 1/500 000ème. Publication de la Direction des Mines et de la Géologie du Cameroun.

[12] Weecksteen, G. (1957) Carte géologique de reconnaissance à l'échelle du 1/500.000 Territoire du Cameroun. Douala Est. Dir. Mines Géol. Cameroun. Paris. 1 carte et notice explicative. Imprimerie Nationale de Yaoundé. 35 p.

[13] Aminov, J., Chen, X., Anming, B., Aminov, J., Mamadjanov, Y., Aminov, J. and Latipa, T. (2019) Comparison of Multi-Resolution Optical Landsat-8, Sentinel-2 and Radar Sentinel-1 Data for Automatic Lineament Extraction: A Case Study of Alichur Area, SE Pamir.

[14] Hung, L.Q., Batelaan, O. and de Smedt, F. (2005) Lineament Extraction and Analysis, Comparison of Landsat ETM and ASTER Imagery. Case Study: Suoimuoi Tropical Karst Catchment. Vietnam, Proceedings of SPIE, 5983, 59830T. https://doi.org/10.1117/12.627699

[15] Adiri, Z., elHarti, A., Jellouli, A., Lhissou, R., Maacha, L., Azmi, M., Zouhair, M. and Bachaoui, M.E. (2017) Comparison of Landsat-8, ASTER and Sentinel 1 Satellite Remote Sensing Data in Automatic Lineaments Extraction: A Case Study of Sidi Flah-Bouskour Inlier, Moroccan Anti Atlas. Advances in Space Research, 60, 2355-2367. https://doi.org/10.1016/j.asr.2017.09.006

[16] Chrysoulakis, N., Abrams, M., Feidas, H. and Arai, K. (2010) Comparison of Atmospheric Correction Methods Using ASTER Data for the Area of Crete, Greece. 
International Journal of Remote Sensing, 31, 6347-6385.

https://doi.org/10.1080/01431160903413697

[17] Gene Rose, Pan Sharpening Tools within Remote View. 13 p. http://imstrat.ca/uploads/files/Brochures/Pansharpening.pdf

[18] Castleman, K. (1995) Digital Image Processing. Prentice Hall, Upper Saddle River.

[19] Veeraraghavan, V. (2004) A Quantitative Analysis of Pansharpened Images. Master Degree of Science, Mississippi State University, Starkville, 94 p.

[20] Eskicioglu, A. and Fisher, P. (1995) Image Quality Measures and Their Performance. IEEE Transactions on Communications, 43, 2959-2965. https://doi.org/10.1109/26.477498

[21] Eldosouky, A.M., Abdelkareem, M. and Elkhateeb, S.O. (2017) Integration of Remote Sensing and Aeromagnetic Data for Mapping Structural Features and Hydrothermal Alteration Zones in Wadi Allaqi Area, South Eastern Desert of Egypt. Journal of African Earth Sciences, 130, 28-37. https://doi.org/10.1016/j.jafrearsci.2017.03.006

[22] Tchindjang, M., Njilah, I.K., Nziengui, M., Banga, C.R. and Menga, V.F. (2006) Caracterisation par l'imagerie satellitale de trois grandes structures d'effondrement dans les hautes terres de l'ouest Cameroun. African Journal of Science and Technology Science and Engineering Series, 7, 8-22.

[23] Prasad, R.K., Mondal, N.C., Pallavi, B., Nandakumar, M.V. and Singh, V.S. (2008) Deciphering Potential Groundwater Zone in Hard Rock through the Application of GIS. Environmental Geology, 55, 467-475.

https://doi.org/10.1007/s00254-007-0992-3 